\title{
Screening of Tetrodotoxin and Its Derivatives in Puffer-related Species
}

\author{
Toshio Saito, ${ }^{* 1}$ Tamao Noguchi, ${ }^{* 1}$ Yasuo Shida, ${ }^{* 2}$ \\ Tokiharu Abe, ${ }^{* 3}$ and Kanehisa Hashimoto** \\ (Received March 6, 1991)
}

\begin{abstract}
Attempts were made to detect tetrodotoxin (TTX) and its derivatives in the following fish species which are phylogenically related to the family Tetraodontidae: spiny puffer "harisenbon" Diodon holacanthus, sunfish "manbou" Mola mola, "uchiwafugu" puffer Triodon bursarius, "kawahagi" filefish Stephanolepis cirrhifer, and "umazurahagi" filefish Navodon modestus. The liver of each species did not show toxicity $(<5 \mathrm{MU} / \mathrm{g}$ ) when assayed by the official method using mice. The liver was extracted with acidic methanol, and the TTX fraction was separated from the extract by the method consisting mainly of ultrafiltration and gel chromatography.

In UV, HPLC, and GC-MS analyses, TTX fraction from spiny puffer showed anyhdroTTX, in addition to a small amount of TTX, which coincided with the phylogenically closest relationship of this species to the family Tetraodontidae.
\end{abstract}

Recent progress in analytical techniques for tetrodotoxin (TTX) and its derivatives (collectively abbreviated TTXs below) makes it possible to detect them at a much lower concentration than that by the mouse assay method. By means of these techniques, bacteria such as Vibrio spp. and Staphylococcus, isolated from the intestines of TTX-bearing organisms, were found to produce TTXs including anhydrotetrodotoxin (anh-TTX). ${ }^{13}$ This suggests that TTXs production by intestinal bacteria may be implicated, at least partly, in the toxification of TTX-bearers. Further, Vibrio spp. are widely distributed in seawater. ${ }^{2)}$ The possibility of toxification is therefore present in fishes other than toxic puffer.

As deseribded previously, ${ }^{3)}$ anh-TTX was clearly detected in nontoxic species of puffer belonging to the family Tetraodontidae. It might also have originated from some intestinal bacteria. But no information is available on the distribution of TTXs in other species of fish.

In this situation, the present work was performed to detect TTXs, more widely, in fish species which are close to the family Tetraodontidae.

\section{Materials and Methods}

\section{Materials}

The following five species of fish, which are phylogenetically related to the family Tetraodontidae, were freshly caught or procured at a fish market. Spiny puffer "harisenbon" Diodon holacanthus (4 specimens), sunfish "manbou" Mola mola (3), "uchiwafugu" puffer Triodon bursarius (2), "kawahagi" filefish Stephanolepis cirrhifer (3), and "umazurahagi" filefish Navodon modestus (2). After being frozen immediately, they were transported to the Laboratory of Marine Biochemistry, and used. Details of those fish specimens are given in Table 1. In addition, TTX was purified from ovaries of "mafugu" puffer Fugu vermicularis porphyreus by the method of Goto et al., ${ }^{4}$ ) and used as reference standard. It contained small amounts of anh-TTX and 4-epitetrodotoxin (4-epiTTX).

\section{Assay for Lethal Potency}

Frozen specimens were partially thawed and the livers dissected. The livers were individually assayed for lethal potency by the official method for TTX using mice..$^{\text {s) }}$

*1 Laboratory of Marine Biochemistry, Faculty of Agriculture, University of Tokyo, Yayoi, Bunkyo, Tokyo

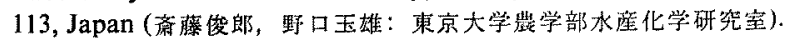

*2Tokyo College of Pharmacy, Hachioji, Tokyo 192-03, Japan (志田保头：東京薬科大学).

*3 The University Museum, University of Tokyo, Hongo, Bunkyo, Tokyo 113, Japan (阿部宗明：東京大学 総合研究資料館).

*4 Food Science Laboratory, Faculty of Education, Ibaraki University, Bunkyo, Mito, Ibaraki 310, Japan (霞本周久: 荻城大学教育学部食物学研營室). 
Table 1. Details of fish species used

\begin{tabular}{|c|c|c|c|}
\hline Fish & $\begin{array}{l}\text { Place and date } \\
\text { of procuration }\end{array}$ & $\begin{array}{l}\text { No. of } \\
\text { specimens }\end{array}$ & Body weight \\
\hline $\begin{array}{l}\text { Spiny puffer } \\
\text { "Harisenbon" } \\
\text { Diodon holacanthus }\end{array}$ & Okinawa Pref. in May '87 & 4 & $79 \sim 119$ \\
\hline $\begin{array}{l}\text { Sun fish } \\
\text { "Manbou" } \\
\text { Mola mola }\end{array}$ & $\begin{array}{l}\text { Manazuru, Kanagawa } \\
\text { Pref. in Sept. " } 87\end{array}$ & 3 & Not weighed \\
\hline $\begin{array}{c}\text { "Uchiwafugu" puffer } \\
\text { Triodon bursarius }\end{array}$ & $\begin{array}{l}\text { Tokyo Wholesale } \\
\text { Fish Market, Tokyo } \\
\text { in Feb. ' } 88\end{array}$ & 2 & $750 \sim 800$ \\
\hline $\begin{array}{l}\text { "Kawahagi" filefish } \\
\text { Stephanolepis cirrhifer }\end{array}$ & $\begin{array}{c}\text { Manazuru, Kanagawa } \\
\text { Pref. in Nov. ' } 87\end{array}$ & 3 & $49 \sim 75$ \\
\hline $\begin{array}{c}\text { "Umazurahagi" filefish } \\
\text { Navodon modestus }\end{array}$ & $\begin{array}{c}\text { Manazuru, Kanagawa } \\
\text { Pref. in Feb. ' } 87\end{array}$ & 2 & $160 \sim 208$ \\
\hline
\end{tabular}

\section{Separation of TTX Fraction}

As shown in Fig. 1, the liver (usually 5 g) was homogenized with 3 volumes of $1 \%$ acetic acid in methanol and centrifuged at $3,000 \mathrm{rpm}$ for

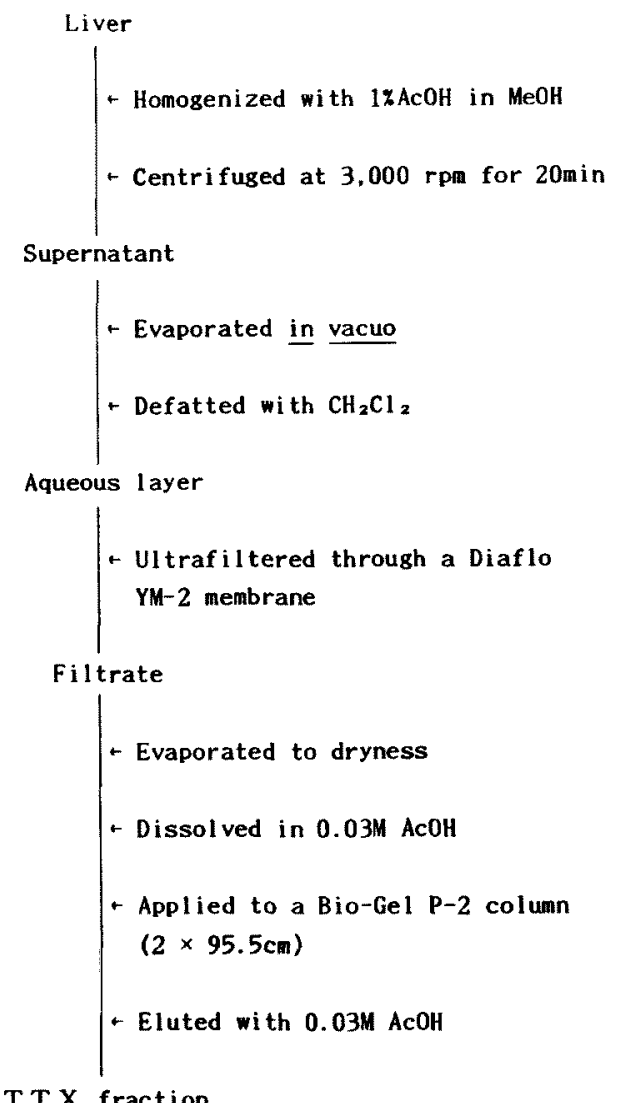

Fig. 1. Procedure of separation of TTX fraction.
$20 \mathrm{~min}$. The residue was extracted two more times in the same way. The supernatants were combined, concentrated in vacuo, and defatted with dichloromethane. The water layer was evaporated to dryness under reduced pressure and dissolved in a small amount of water. The solution was filtered through a Diaflo YM-2 membrane (Amicon, Danvers, MA., Ireland) whose cut-off limit was $1,000 \mathrm{Da}$. The filtrate was evaporated to dryness and dissolved in a small amount of $0.03 \mathrm{M}$ acetic acid. The solution was chromatographed on a Bio-Gel P-2 column $(2 \times 95.5 \mathrm{~cm})$ using $0.03 \mathrm{~m}$ acetic acid. The fractions corresponding to authentic TTXs were combined and lyophilized. "TTX fraction", or the fraction corresponding to authentic TTXs, was collected and lyophilized. TTX fraction thus obtained was analyzed for TTXs, as described below. ${ }^{3)}$

\section{High Performance Liquid Chromatography (HPLC)}

A portion of TTX fraction was examined by reverse phase HPLC on a YMC AM-314 (Yamamura Riken, Kyoto) column $(0.6 \times 30 \mathrm{~cm})$ with heptanesulfonic acid as ion-pairing reagent, as reported previously. ${ }^{\text {i) }}$ The eluate was mixed with an equal volume of $3 \mathrm{~N} \mathrm{NaOH}$ at a flow rate of $1 \mathrm{~m} / / \mathrm{min}$ and heated in a reaction coil at $100^{\circ} \mathrm{C}$ for $0.4 \mathrm{~min}$. The resulting flourophors were monitored by a Hitachi $650-10 \mathrm{M}$ fiuorospectrometer at $505 \mathrm{~nm}$ with excitation at $380 \mathrm{~nm}$.

\section{UV Spectrophotometry}

Another portion of TTX fraction was dissolved in $1 \mathrm{~m} l$ of $1.5 \mathrm{~N} \mathrm{NaOH}$ and heated at $100^{\circ} \mathrm{C}$ for 45 min. $^{7)}$ After being cooled to room tem- 
perature, the degradation product was subjected to UV spectrophotometry to confirm the formation of the $\mathrm{C}_{9}$-base, 2-amino-6-hydroxymethyl-8hydroxyquinazoline.

\section{Gas Chromatography-Mass Spectrometry (GC-} $M S$ )

The above alkali-degradation product was adjused to $\mathrm{pH} 3-5$ with $10 \% \mathrm{HCl}$ and extracted

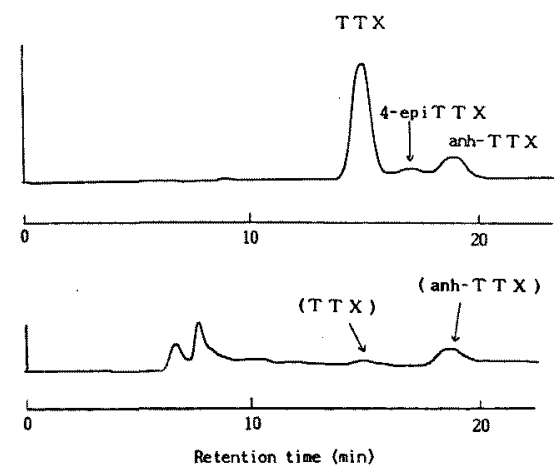

Fig. 2. HPLC of TTX fraction from spiny puffer (lower) and of authentic TTXs (upper).

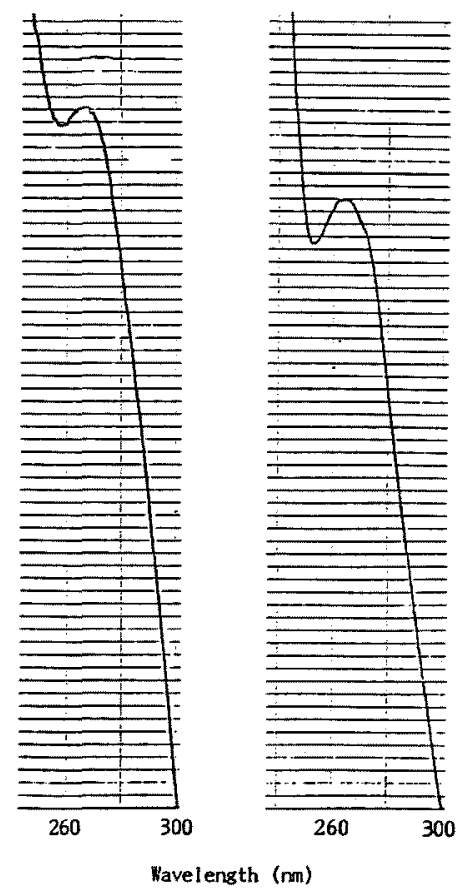

Fig. 3. UV absorption spectra of the alkali-degradation product from spiny puffer TTX fraction (left) and from authentic TTXs (right). three times with $5 \mathrm{~m} l$ each of 1-butanol. The extracts were combined and evaporated to dryness in vacuo, and to the residue was added a mixture of $\mathrm{N}, \mathrm{O}$-bis (trimethylsilyl) acetamide, trimethylchlorosilane, and pyridine $(2: 1: 1)$, in order to trimethylsilylate the $\mathrm{C}_{\mathrm{g}}$-base." The derivative obtained was submitted to GC-MS on a Hitachi M-80 GC-mass spectrometer. A column $(0.3 \times 200 \mathrm{~cm})$ of $1.5 \%$ silicon OV-101 Chromosorb W (60 80 mesh) was used. The temperature was programmed from $160^{\circ} \mathrm{C}$ to $250^{\circ} \mathrm{C}$ at a rate of $5^{\circ} \mathrm{C} / \mathrm{min}$ and the flow rate of inlet helium gas was $40 \mathrm{~m} / \mathrm{min}$. Ionizing voltage was $70 \mathrm{eV}$ and the ion was accelerated at $3 \mathrm{kV}$. Ion source temperature was kept at $200^{\circ} \mathrm{C}$.

\section{Results}

\section{Spiny Puffer}

None of the specimens of this species showed any lethal potency, when the liver extract was assayed by the official method for TTX. ${ }^{\text {) }}$ In HPLC, the TTX fraction from each specimen
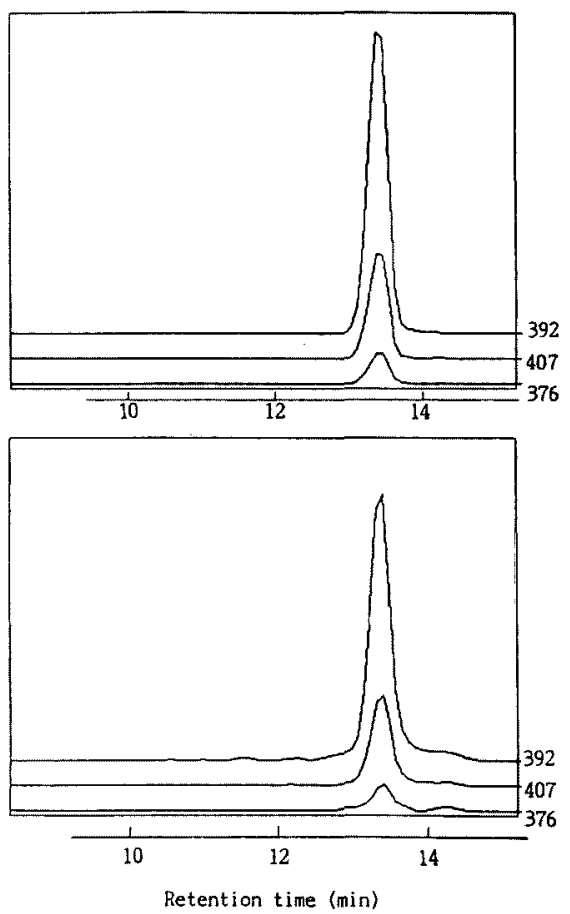

Fig. 4. Ion-monitored chromatograms of the TMS derivative from alkali-degraded TTX fraction of spiny puffer (lower) and from alkali-degraded TTXs (upper). 

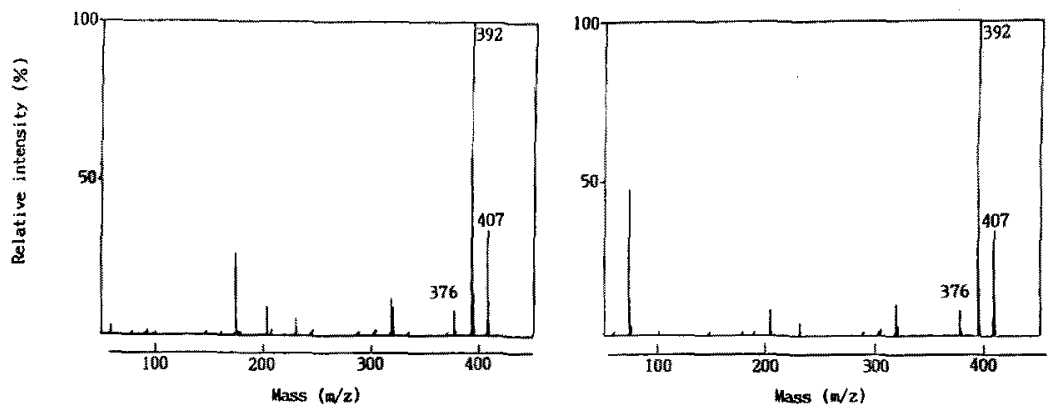

Fig. 5. Mass spectra of the TMS derivative from alkali-degraded TTX fraction of spiny puffer (left) and from alkali-degraded TTXs (right).

gave rise to several peaks, two of which showed the same retention times as those of TTX and anh-TTX, respectively, though the peak of TTX was very small. An example of the HPLC pattern is depicted in Fig. 2.

Figure 3 shows a UV absorption spectrum of the alkali-degradation product from TTX fraction, along with that of the corresponding product from TTX. The degradation product from spiny puffer exhibited an absorption maximum at around $270 \mathrm{~nm}$, indicating the formation of the $\mathrm{C}_{9}$-base.

Figure 4 shows the ion-monitored chromatograms of the trimethylsilyl derivatives prepared from authentic TTX and spiny puffer TTX fraction. Mass fragment ions at $\mathrm{m} / \mathrm{z}$ 376, 392, and 407 which are characteristic of the $\mathrm{C}_{8}$-base, appeared at the same retention time $(12.7 \mathrm{~min})$ in both chromatograms. Both of those peaks from authentic TTX and spiny puffer TTX fraction elicited essentially the same mass spectra which were featured by fragment ions at $\mathrm{m} / \mathrm{x}$ 407 (molecular peak), 392 (base peak), and 376 (Fig. 5).

\section{Other Species of Fish}

No specimen of other fish species showed any lethal potency in the mouse bioassay. Neither TTX nor its derivatives were detected at all, in HPLC, UV spectrophotometry, and GC-MS.

\section{Discussion}

In a previous paper, ${ }^{2}$ we reported the occurrence of TTXs in the liver of two nontoxic puffer species, "shirosabafugu" Lagocephalus wheeleri and "yoritofugu" Sphoeroides pachygaster, both of which belong to the family Tetraodontidae. In the present study, we detected small amounts of these substances only in spiny puffer of the five puffer-related species. However, any specimen of spiny puffer was nontoxic. It is interesting that the distribution of TTXs was extended to this diodontid species of fish.

As previously reported ${ }^{\text {s }}$ we assayed some seven hundred specimens of cultured "torafugu" puffer Fugu rubripes rubripes for lethal potency and found no toxic specimen, regardless of collection site, age, and tissue of specimen. These specimens were, however, easily toxified when fed on a TTX-containing diet, indicating that toxification of puffer is closely associated with feeding or the food chain. Other fish species except for spiny puffer could feed on a diet which diodontid and tetraodontid fish do not feed. Much more physiological and ecological information on puffer and related species is needed to elucidate the physiological significance of TTXs in them. On the other hand, the process of toxification during evolution of puffer may give a clue in this respect. This is one of the reasons why puffer-related species were used in the present study.

Tyler $^{9 \%}$ described that tetraodontid fish is phylogenetically close to diodontid fish. Fujita ${ }^{10)}$ suggested that spiny puffer and a puffer "sabafugu" Lagocephalus lunaris spadiceus phylogenetically predated another puffer "torafugu", on the basis of morphological and ecological comparisons. In other words, toxic pufferes as represented by "torafugu" evolved from the types such as spiny puffer or "sabafugu". As puffer changed habitat from the surface to bottom of the sea due to some unknown cause(s), they could have acquired biological structures for having TTX. The occurrence of TTXs in spiny puffer seems to support the Fujita's hypothesis.

As we reported previously, 11 "sabafugu" 
showed a TTX resistibility which was intermediate between toxic puffer species and other teleosts, supporting also the hypothesis. In this conrection, it seems interesting to assay TTX resistibility of spiny puffer.

Further studies are now in progress.

\section{Acknowledgments}

The present study was supported in part by a grant from the Ministry of Education, Science, and Culture of Japan.

\section{References}

1) T. Noguchi, J.-K. Jeon, O. Arakawa, H. Sugita, Y. Deguchi, Y. Shida, and K. Hashimoto: $J$ : Biochem., 99, 311-314 (1986).

2) H. Sugita and Y. Deguchi: In "Recent Advances in Tetrodotoxin Research" (ed. by K. Hashimoto), Fisheries Science Series No. 70, Koseisha-koseikaku, Tokyo, 1988, pp. 65-75.

3) T. Saito, S. Kanoh, T. Noguchi, Y. Shida, and K. Hashimoto: In "Progress in Venom and Toxin Research" (ed. by P. Gopalakrishnakone and C.-K. Tan), National University of Singapore, Singapore, 1987, pp. 314-324.

4) T. Goto, S. Takahashi, Y. Kishi, and Y. Hirata: Tetrahedron, 21, 2059-2088 (1965).

5) T. Kawabata: In "Shokuhin Eisei Kensa Shishin II" (ed. by Enivronmental Health Bureau, Ministry of Health and Welfare), Nippon Shokuhin Eisei Kyoukai, Tokyo, 1978, pp. 232-240.

6) Y. Nagashima, J. Maruyama, T. Noguchi, and K. Hashimoto: Nippon Suisan Gakkaishi, 53, 819-823 (1987).

7) T. Noguchi, J. Maruyama, Y. Ueda, K. Hashimoto, and T. Harada: Nippon Suisan Gakkaishi, 47, 909-913 (1981).

8) T. Saito, J. Maruyama, S.-K. Jeon, T. Noguchi, T. Harada, O. Murata, and K. Hashimoto: Nippon Suisan Gakkaishi, 50, 1573-1575 (1984).

9) J. C. Tyler: In "NAOO Technical Report NMFS Circular 434", U. S. Department of Commerce, Seattle, 1980, pp. 4-7.

10) Y. Fujita: In "Nagasaki Ken Suisanshikenjyo Ronbunshu-2" (ed. by Fisheries Experiment Station of Nagasaki Pref.), 1962, pp. 1-121.

11) T. Saito, T. Noguchi, T. Harada, O. Murata, T. Abe, and K. Hashimoto: Nippon Suisan Gakkaishi, 51, 1371 (1985). 